\title{
Development of the Human Capital Taking into Account a Gender Factor in Russia
}

\author{
Inna Sergeevna Bogomolova
}

\author{
Svetlana Victorovna Grinenko
}

\section{Elena Konstantinovna Zadorozhnyaya}

Southern Federal University 05/42 Bolshaya Sadovaya Str., Rostov-on-Don, 344006, Russia

Email: isbogomolova@sfedu.ru, svgrinenko@sfedu.ru, ekzadorozhnyaya@sfedu.ru

\section{Doi:10.5901/mjss.2015.v6n3s4p237}

\begin{abstract}
To questions of a gender inequality, professional segregation in Russia, unlike world practice, for many years it wasn't paid sufficient attention that caused interest of authors to this problem. As object of research in article the human capital of the territory which analysis is submitted at the state and regional level, a subject-gender aspect as one factors of the human capital development acts. In article on the basis of methods of generalization, comparison, the statistical analysis, an assessment of dynamics ranks, the analysis of the human capital reproduction processes in Russia and the Southern federal district is carried out; the analysis of the human capital development in the Southern Federal District taking into account gender features; assessment of the directions of achievement of gender equality and its influence on social and economic development. By results of the carried-out analysis conclusions were drawn on a remaining gender gap in life expectancy, an education level, the income; about asymmetry on the labor market, being shown in a rupture of an education level of women, their level of economic activity and returns from investments and the reached level of the human capital; about remaining unequal access to economic resources and lack of the adequate gender policy meeting standards of international law, to Conventions of the UNO and other international organizations. It allowed to formulate the directions of an institutionalizing of gender equality as component, a condition and a resource of development of economy.
\end{abstract}

Keywords: human capital, gender, gender inequality.

\section{Introduction}

Now development of Russian economy appreciably depended on such source of growth, as a human capital that are cause by high-quality change of economic, social and political conditions of the social development connect with forming of knowledge economy, increase in differentiation of Russian territories against processes of globalization and in education. The concept of national economy development determined process of a human capital reproduction in federal districts of Russia as a point of growth. The human capital resource are capable to provide innovative development of economy (Bogomolova and Masych, 2011).

It are necessary to overcome available negative tendencies in development of a human capital for development of the Southern federal district (SFD), such as: reducing of population and an employment level in economy; a growth of competition on a labor market concerning efficient personnel; decrease in quantity of the employment population at the enterprises of real economy; low quality and decrease in level of availability of social services in sphere of a health care and education.

According to the Concept of long-term social and economic development of the Russian Federation for the period till 2020th year development of human potential included system transformations of two types: direct on increase of competitiveness of personnel potential, work-force and social sectors of economy; improving quality of a social environment and living conditions of people. This transformations covered medium-term and long-term objectives, priorities and the basic directions of a demographic policy, a policy of modernization of a health care and education, development of pension sphere and the social care, development of culture, forming of effective labor markets and habitation.

The aforesaid had specify an orientation of research on detail of a human capital development in the SFD as the subject of the Russian Federation possess a number of specific details, determine by geoeconomy and ethnoeconomy factors. Research aspects of reproduction of a human capital, it is obviously necessary to pay attention it to interdependency with demographic reproduction of the population of Russia in the course of who developed both 
quantitative and quality parameters taking into account regional specificity (Borovskaya et al., 2012).

\section{Southern Federal District as Specific Segment of Russian Labor Market}

Specification of the presented indicators in a section of subjects about the SFD (tab. 2) is necessary for further research. The all-Russian tendencies remain in regions of the SFD: the greatest number of citizens have the secondary vocational education, approximately the higher and general education, at the same time a share of the population which has got a postgraduate education, rather low have equal number of persons. Data on the Astrakhan region differ a little - the maximum number of the population has secondary vocational educations at lower in comparison with other subjects of shares of the higher and postgraduate education. Statistical data testify that the population education level is higher; the level of its economic activity is higher. Existence of vocational education promotes also to employment opportunities. Higher education level allows the employment population to receive «better» workplaces: stable and bringing in higher income (Roshchina, 2005) that is to be demanded on a labor market.

Table 2. Structure of the population of Russia, the SFD and its subjects on an education level (\%) (Regions of Russia. Socio-economic indexes. Statistical collection, 2012-2013)

\begin{tabular}{|c|c|c|c|c|c|c|c|c|c|}
\hline & \multicolumn{8}{|c|}{ Employment in economy } & \multirow{3}{*}{ 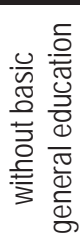 } \\
\hline & \multicolumn{5}{|c|}{ Vocational education } & \multicolumn{3}{|c|}{ General education } & \\
\hline & 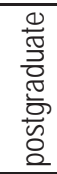 & 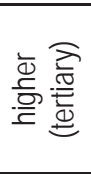 & 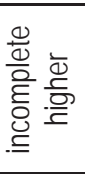 & 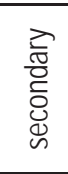 & 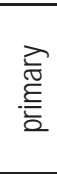 & $\begin{array}{l}\frac{\bar{\pi}}{\overline{0}} \\
\frac{\bar{d}}{0}\end{array}$ & 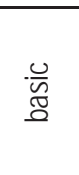 & $\begin{array}{l}\frac{0}{0} \\
\widetilde{0} \\
0 \\
\overline{0} \\
\underline{0}\end{array}$ & \\
\hline Russian Federation & 0,6 & 22,8 & 4,6 & 31,2 & 5,6 & 18,2 & 11,0 & 5,4 & 0,6 \\
\hline Southern Federal District & 0,6 & 20,8 & 4,1 & 30,6 & 5,4 & 20,1 & 11,9 & 5,9 & 0,6 \\
\hline Krasnodar Krai & 0,5 & 20,5 & 4,0 & 29,6 & 5,0 & 21,7 & 12,3 & 5,9 & 0,5 \\
\hline Volgograd region & 0,4 & 20,7 & 4,0 & 32,5 & 5,8 & 19,0 & 11,1 & 5,8 & 0,7 \\
\hline Rostov region & 0,6 & 21,6 & 4,3 & 30,0 & 6,0 & 18,9 & 11,9 & 6,1 & 0,6 \\
\hline Astrakhan region & 0,6 & 18,1 & 3,9 & 35,1 & 5,0 & 18,2 & 11,9 & 6,1 & 1,1 \\
\hline Republic of Adygea & 0,5 & 20,8 & 4,1 & 28,8 & 5,1 & 21,1 & 12,7 & 6,1 & 0,8 \\
\hline Republic of Kalmykia & 0,5 & 21,7 & 4,8 & 27,5 & 3,7 & 22,3 & 12,1 & 6,2 & 1,2 \\
\hline
\end{tabular}

Qualitative problems of the human capital development are connected with requirements of technological development of the Russian economy to qualified personnel. Owing to what improvement of quality of the human capital assumes education of new system of preparation and retraining of personnel, which would be adapted for modern conditions of innovative strategy of development of economy, including basic updating of all system of the social and labor relations (Labor in the USSR (The statistical reference book), 1932).

Table 3. The main socio-economic indexes of regions of the SFD in 2011 (Regions of Russia. Socio-economic indexes. Statistical collection, 2012-2013)

\begin{tabular}{|l|c|c|c|c|c|c|c|c|c|}
\hline \multirow{2}{*}{ Region of the SFD } & $\begin{array}{c}\text { GRP (billion } \\
\text { rubles) }\end{array}$ & \multicolumn{2}{|c|}{$\begin{array}{c}\text { Population (thou. } \\
\text { persons) }\end{array}$} & $\begin{array}{c}\text { Average annual number } \\
\text { employment in economy } \\
\text { (thou. persons) }\end{array}$ & \multicolumn{2}{|c|}{$\begin{array}{c}\text { Average per capita } \\
\text { money income (monthly } \\
\text { rubles) }\end{array}$} & $\begin{array}{c}\text { Investments into } \\
\text { fixed capital (billion } \\
\text { rubles) }\end{array}$ \\
\cline { 2 - 11 } & 2011 & 2011 & 2012 & 2011 & 2012 & 2011 & 2012 & 2011 & 2012 \\
\hline Krasnodar region & 1229,7 & 5284,5 & 5330,2 & 2288,5 & 2328,3 & 18796,0 & 21077,2 & 676 & 797 \\
\hline Volgograd region & 761,8 & 4260,6 & 4254,6 & 1902,2 & 1912,4 & 16010,3 & 17987,3 & 155 & 198 \\
\hline Rostov region & 498,9 & 2594,8 & 2583,0 & 1226,1 & 1252,9 & 14519,4 & 16066,4 & 101 & 126 \\
\hline Astrakhan region & 170,5 & 1015,0 & 1013,9 & 448,5 & 442,5 & 16032,0 & 17773,4 & 68 & 81 \\
\hline Republic of Adygea & 55,2 & 442,4 & 444,4 & 151,9 & 152,0 & 14271,6 & 17025,3 & 16 & 15 \\
\hline Republic of Kalmykia & 28,7 & 286,7 & 284,1 & 113,6 & 113,0 & 8829,4 & 10183,8 & 9 & 14 \\
\hline
\end{tabular}

Research of the human capital assumes need of the accounting of a factor of discrimination character - the gender conflict blocking an effective allocation of resources and undermining a basis of progressive social and economic 
dynamics through institutional fixing and formalization of an inequality of opportunities of individuals that is shown in structural deformation of society: growth of expenses of the management, the slowed-down growth of labor productivity and, as a result, braking of process of transition to an innovative way of economic development (Petukhova, 2008).

The analysis of position of gender groups in Russia shows that a basis of a gender inequality and discrimination are unequal position of men and women in the economic sphere (various return from the human capital, unequal access to economic resources) and remaining and even an amplifying inequality on health level. Localization of a such inequality and discrimination is caused by realization of a package of measures of long-term impact on society and its institutes (Petukhova, 2008).

The assessment of a level of development of the human capital in the region is based on indicators of social and economic development of the subjects which are a part of the SFD leading regions in which are Krasnodar Krai, the Rostov and Volgograd regions (tab. 3): the most part of the population, the gross regional product (GRP) high level lives in them, the average monthly nominal added salary, the average per capita monetary income.

\section{Influence of gender factors on Development of the Human Capital of the Local Territory}

In the international practice, pay special attention to the gender indicators, which are important at an assessment of the human capital, as the factor influencing quality, mobility, qualification characteristics of a work-force. Tendencies of involvement of women in a labor market differ in different economic systems that defined high employment of women in Russia as a result of existence of centrally operated economy (Ogloblin, 2005). It is confirmed by the analysis of concentration of women in the economy branches, presented in tab. 4.

Table 4. Branch concentration of women in economy of Russia, 1980-2012, \% (The Russian Federation in 1992 (Statistical year-book), 1993; Labor in the USSR (The statistical reference book), 1932)

\begin{tabular}{|l|c|c|c|c|c|c|c|c|}
\hline & 1980 & 1985 & $\mathbf{1 9 9 0}$ & $\mathbf{1 9 9 6}$ & $\mathbf{2 0 0 0}$ & $\mathbf{2 0 0 5}$ & $\mathbf{2 0 1 0}$ & $\mathbf{2 0 1 2}$ \\
\hline TOTAL & 52 & 52 & 52 & 47 & 48 & 49 & 49 & 49 \\
\hline Agriculture & 42 & 41 & 40 & 34 & 39 & 39 & 35 & 36 \\
\hline Industry & 49 & 48 & 48 & 41 & 43 & 43 & 41 & 40 \\
\hline Construction & 29 & 28 & 27 & 24 & 22 & 19 & 16 & 15 \\
\hline Wholesale and retail trade & 80 & 79 & 80 & 62 & 60 & 61 & 62 & 62 \\
\hline Hotels and restaurants & $\ldots$ & $\ldots$ & $\ldots$ & $\ldots$ & 84 & 78 & 77 & 77 \\
\hline Transport and communication & 25 & 25 & 25 & 26 & 29 & 31 & 28 & 27 \\
\hline Communication & 71 & 71 & 71 & 62 & $\ldots$ & $\ldots$ & $\ldots$ & $\ldots$ \\
\hline Financial activity & 87 & 89 & 90 & 74 & 65 & 64 & 67 & 67 \\
\hline Operations with real estate, rent and service & $\ldots$ & $\ldots$ & $\ldots$ & $\ldots$ & 45 & 44 & 42 & 42 \\
\hline Public administration and ensuring military safety & 69 & 71 & 67 & 50 & 33 & 38 & 40 & 41 \\
\hline Education & 79 & 78 & 78 & 82 & 79 & 80 & 81 & 81 \\
\hline Health care and providing social services & 85 & 84 & 83 & 82 & 82 & 82 & 80 & 80 \\
\hline $\begin{array}{l}\text { Providing other municipal, social, personal and other } \\
\text { services }\end{array}$ & 54 & 54 & 52 & 46 & 52 & 67 & 69 & 70 \\
\hline
\end{tabular}

The share of women among taken in economy according to 1932 made $27 \%$, by 1950 grew and reached level of $41 \%$ and in 1960 (in 10 years) changed on 18 points - 59\% - the most observed value. Military and post-war years fell on this period - women owing to the objective reasons assumed man's work in the years of World War II and continued to work in a priori man's branches during the economic recovery, at the same time being the period of restoration of demographic balance (tab. 5). By 1969 level made 50\% and after that changes happened within 3 points and by 2012 the share of women among the busy made $49 \%$.

Accepting the approach which is based on definition of existence of a gender segregation at difference of an employment rate of women/men in branch from an employment rate of women in economy as a whole, it should be noted the following tendencies, including basic 1980:

_ in base year to «man's» branches (concentration of men from 70\%) construction and transport, to «female» (concentration of women is higher than $70 \%$ ) - trade, communication, financial activity, public administration and insurance, belonged to intermediate branches - agriculture and processing productions;

- next 10 years (by 1990) growth of man's participation in spheres of agriculture and public administration is 
observed, and it is rather «leaving» of women the called branches owing to automation of a number of processes. It should be noted also that in both branches of the woman held low-paid positions and workplaces;

- next decade further advance of men in the above-designated branches, and also trade, communication, the financial sphere is observed;

- by 2012 agriculture - almost «man's» branch ( $64 \%$ of men), in construction of the woman are actually forced completely out from branch ( $85 \%$ of men), in trade and public administration - the share of men grew twice, in financial activity - by 2,5 times.

The researchers working within the theory of gender testify that professional «preferences» of women are caused not by physiological distinctions, and a certain way of public life (Youth in Russia. Statistical collection, 2010). The gender gap is defined by set of factors, among which, certainly, regional distinctions.

The analysis of gender indicators of subjects of the SFD (tab. 6) testifies to existence of a gender inequality in the field of compensation against excess of number of women as a part of a work-force: the number of women in all regions exceeds the number of the men, the greatest excess is observed in the Volgograd region.

Table 5. Share of women in population of the USSR (Number, structure and movement of the population of the USSR. Statistical materials, 1965)

\begin{tabular}{|c|c|c|c|}
\hline Age groups & 1939 year & 1959 year & 1964 year \\
\hline $20-24$ & $52 \%$ & $51 \%$ & $50 \%$ \\
\hline $25-29$ & $51 \%$ & $51 \%$ & $51 \%$ \\
\hline $30-34$ & $50 \%$ & $55 \%$ & $51 \%$ \\
\hline $35-39$ & $53 \%$ & $61 \%$ & $55 \%$ \\
\hline $40-44$ & $54 \%$ & $62 \%$ & $61 \%$ \\
\hline $45-49$ & $55 \%$ & $62 \%$ & $62 \%$ \\
\hline $50-54$ & $55 \%$ & $62 \%$ & $62 \%$ \\
\hline $55-59$ & $60 \%$ & $67 \%$ & $63 \%$ \\
\hline $60-64$ & $59 \%$ & $65 \%$ & $66 \%$ \\
\hline $65-69$ & $60 \%$ & $65 \%$ & $67 \%$ \\
\hline 70 years also are more & $63 \%$ & $68 \%$ & $69 \%$ \\
\hline
\end{tabular}

In all regions of the SFD the greatest level of economic activity is shown by men, also at men in all regions level of a salary is higher, than at women that testifies to lower extent of participation of women in work and more limited opportunities of employment of women on primary and secondary segments of a labor market. Certainly, gender disproportions in a context of development of the human capital are defined by a set of factors among which it should be noted essential negative influence of existence and number of children. This result is easily explainable, after all on women the main loading connected with the birth and education of children (Roshchin, 2003) lays down.

In the Astrakhan region the salary of men is $45 \%$ higher than at women, in other regions the difference makes 30 $35 \%$. Only in the Republic of Kalmykia the lowest value of this indicator, namely, $-21 \%$ is observed. Thus, it is less than unemployment women, than unemployment men in all regions of the SFD. The difference in earnings of men and women, as a rule, is explained by an inequality in distribution of men and women by separate professions and branches (a horizontal segregation), an inequality in a salary within professions and kinds of activity (a vertical segregation), and a low estimate of that work in which women are engaged. If distinctions in qualitative characteristics of labor of men and women were the main cause of unequal remuneration, it would be possible to expect that identical indicators of a level of economic activity and an education level will lead and to identical level of a salary, however it does not occur (Roshchin, 2005).

To problems of gender equality in Russia it is not paid sufficient attention, programs aren't realized, the statistics doesn't gather. Owing to these reasons, data on distribution being trained on various levels of training are available only as a whole about the country. Assuming analogousness of tendencies, it should be noted that according to programs of primary vocational education during the period from 2000 to 2012 were education from 38 to $36 \%$ of women, according to programs of secondary vocational education in the public and municipal authorities for the same period it was education from 50 to $46 \%$ of women, according to higher education programs - level practically didn't change $-57-56 \%$. Thus in postgraduate education growth of participation of women - for postgraduate study from $43 \%$ in 2007 to $46 \%$ in 2011 is observed, for doctoral studies - growth made $2 \%$ and in 2011 this indicator made 48\% of being education women. These 
data confirm distinctions in structure of the human capital: women on the average have higher education level, but give preference to arts and pedagogical education. As other factors the saved up experience, the professional life - women interrupt work during the birth and childrearing, thus experience which is actual for career, collects just during those periods of life cycle and at that age when women have a high probability of a break in work. Thus, they can lose launching sites to men. (Roshchin and Solntsev, 2006).

Table 6. The analysis of gender groups of regions of the Southern Federal District on a level of economic activity, a salary and to structure of the unemployed, 2011 (Women and men of Russia. Statistical collection, 2012)

\begin{tabular}{|c|c|c|c|c|c|c|c|}
\hline \multirow[t]{2}{*}{$\begin{array}{l}\text { Regions of the Southern } \\
\text { Federal District }\end{array}$} & \multicolumn{2}{|c|}{$\begin{array}{c}\text { Economically active } \\
\text { population on the average for } \\
\text { a year (\%) }\end{array}$} & \multicolumn{2}{|c|}{$\begin{array}{c}\text { Average monthly wages of } \\
\text { employees of organizations } \\
\text { (rub) }\end{array}$} & \multirow{2}{*}{$\begin{array}{c}\text { Relation wages of } \\
\text { women to a wages of } \\
\text { men (\%) }\end{array}$} & \multicolumn{2}{|c|}{$\begin{array}{l}\text { Structure of the } \\
\text { unemployed (\%) }\end{array}$} \\
\hline & male & female & male & female & & male & female \\
\hline Krasnodar Krai & 71,9 & 57,4 & 23155 & 14655 & 63 & 81 & 73 \\
\hline Volgograd region & 72,2 & 59,5 & 22026 & 14289 & 65 & 82 & 76 \\
\hline Rostov region & 72,5 & 60,3 & 20828 & 13878 & 67 & 50 & 42 \\
\hline Astrakhan region & 76,6 & 61,9 & 24168 & 13252 & 55 & 24 & 24 \\
\hline Republic of Adygea & 68,5 & 55,7 & 16749 & 11967 & 71 & 10 & 7 \\
\hline Republic of Kalmykia & 72,4 & 61,7 & 13297 & 10511 & 79 & 12 & 8 \\
\hline
\end{tabular}

The social construction of a female gender assumes big alternativeness of behavior. Women can be realized both in the business sphere, and in family, or to resort to the mixed strategy of a combination of employment. Men have no such alternativeness, for them career, success - the only option of behavior. The social construction of a man's gender is set much more rigidly and is uncontested. Success, and understood as success outside family life, success in the business sphere, is one of system parameters of a man's gender. Besides, for the SFD the ethnoeconomic and geoeconomic factors defining a role of the woman in a family (the Republics of Adygea, Kalmykia) and branch orientation of regions with prevailing agriculture and a recreational complex are important.

It should be noted preservation of the Russian dependence also: the stable situation on a labor market leads to decrease in competitiveness of women. Thus, women use the strategy of a survival defining big, in comparison with men, readiness for decrease in the social and professional status more often. It leads to that, despite the minimum and being reduced gender inequality in the employment, steady remains both horizontal, and the vertical professional segregation of women causing considerable gender disproportions in compensation.

The relation of a salary of women and men about the country averaged 64\% in 2011 - the same level is observed in the Rostov region and Krasnodar Krai. Thus, the lowest level of a salary of women - $55 \%$ is observed in the Astrakhan region, the highest - in the Republic of Kalmykia. It finds an explanation in branch orientation of the subject of the SFD in the Astrakhan region the maximum share of VRP is the share of «man's» branches - mining $(19,2 \%)$, construction $(12,5 \%)$, transport and communication $(12,2 \%)$, and in the Republic of Kalmykia on agriculture $(34,2 \%)$, public administration (16,6\%) where salaries are distributed more evenly. Besides, in Kalmykia the high share of VRP (maximum in the SFD) is the share of health care and rendering social services $-7,1 \%$ and education $-6,6 \%$ which also assume almost equal compensation - the indicator across Russia made in $201183,3 \%$ and $89 \%$ respectively that once again testifies to a gender inequality of level of the human capital and compensation corresponding to it.

These conclusions are confirmed also by FSSS RF researches: comparison of compensation of men and the women entering the same categories of the personnel showed that on all categories the average salary of men exceeded an average salary of women. This indicator fluctuates from $57 \%$ in the establishments, which are carrying out activity on the organizations of rest and entertainments, culture and sports, to $96 \%$ in the organizations, which are carrying out production and distribution of the electric power, gas and water.

It should be noted that Russia constantly reduces the positions in a rating of gender discrimination in the countries, presented Global Gender Gap Report-2013 (fig. 5).

Since 2006 Russia lowered the positions on 12 points and takes in 201361 places among 134 countries, thus showing positive dynamics only on participation of women in policy and health indicators that compensated falling of level of economic participation of women on 20 points - from 22 places on 42, and also level of availability of education - on 27 positions. This situation is directly connected with lack of the gender policy, institutes providing its realization, the acts regulating gender equality in access to education, to leading posts, policy. 

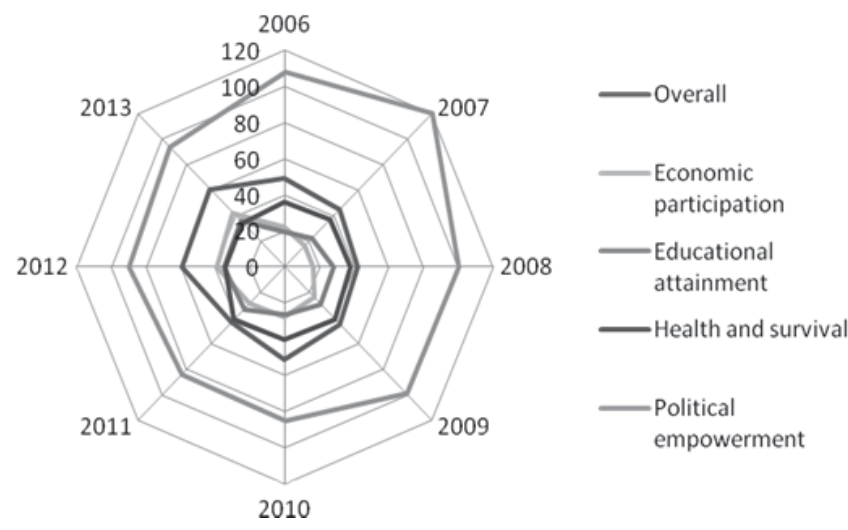

Figure 5. Positions of Russia in a rating of gender discrimination (Work and employment in Russia. 2013: Statistical collection, 2013)

\section{Concluding Remarks}

In conclusion, of the above it is possible to allocate the following main problems of achievement of gender equality in Russia:

- remaining gender gap in life expectancy, an education level, the income;

- asymmetry on a labor market which is shown that the education level of women is higher, unemployed among women is less, than among men, however, the income and a level of economic activity of men is higher, than at women;

- unequal access to economic resources;

- lack of the adequate gender policy meeting standards of international law, to Conventions of the UNO and other international organizations.

In strategy of development of the international organizations a problem of gender equality as the component of social and economic development takes a priority place when forming a state policy. The thesis of achievement of gender equality in a context of social justice and thesis about gender equality as the factor defining sustainable social and economic development are reasoned. Use of world experience staticizes need of an institutionalization of gender equality and for Russia. This process happens in many states, is declared by the international organizations (the UNO, the World Bank and so forth) world forums. In Russia there is no the institute/mechanism allocated with special powers, defining the directions and programs of achievement of the gender equality, possessing sufficient resource potential for implementation of the called functions and the solution of problems of a gender segregation. The gender inequality negatively influences society development as a whole and its social and economic component in particular, causing increase of expenses of wellbeing, work decline in production, delay of economic growth, GDP growth and the income per capita. The institutionalizing of development of the gender equality which is not only an important component of the human capital level growth, but also a condition of innovative transformation of economy has to become permission of current situation. The national paradigm of development of gender equality has to include not only formal institutes, but also informal rules, norms and the structures supplementing each other that will allow reaching synergetic effect and goals of transformation of economy.

The results of research presented in this paper were obtained with the financial support of the Ministry of Education of the Russian Federation within the framework of the project "Creation of a plant for manufacture of multifunctional mobile hardware-software complex of prolonged cardiac monitoring and ergometry" by government decree № 218 of 09.04.2010, the research was carried out in the FSAEI HPE SFU (SFedU).

\section{References}

Beglova, E.I. (2010). Youth unemployment: prime problem of a modern labor market. Economy and management - economic sciences, 11(72), 172-175.

Bendyukov, M.A., Savrilova, N.S., Solomin, I.L. (2007). Research of features of system of the relations of the unemployed to various aspects of unemployment. News of RSPU (Herzen university), 30, 31-46.

Bechvaya, M.R., Borovskaya, M.A., Masych, M.A. (2012). Analysis of modern system of the social and labor relations. SFEDU News. 
Technical science, 8, 15-21.

Bogomolova, I.S., Zadorozhnyaya, E.K. (2013). Statistical comparison of parameters of development of labor potential in modern conditions. SFEDU News. Technical science, 6, 17-24.

Bogomolova, I.S., Masych, M.A. (2011). Reproduction of labor potential in system of social and economic and demographic factors. SFEDU News. Technical science, 11 (124), P. 17-23.

Grinenko, S.V., Zadorozhnyaya, E.K. (2013). Development of education and sciences as major factor of the human capital, SFEDU News. Technical science, 124 (11), 23-27.

Statistical collection. (2012). Women and men of Russia. Moscow: Rosstat.

Kambotova, Zh.V. (2008). Social adaptation of youth in the conditions of unmployment. Newspaper «Adyghe state university», Series 1 , $8,245-250$.

Maltseva, I.O., Roshchin, of S. Yu. (2007). Gender segregation and labor mobility, Moscow: Prod. SU HSE house.

Statistical collection. (2010). Youth in Russia. UNICEF, Moscow: Rosstat.

Petukhova, I.Yu. (2008). Quality and population standard of living as criterion function of the state, Institutional and economic researches, 2 (26).

Petukhova, I.Yu. (2008). Specificity of female labor migration from Russia, Terra economicus (Newspaper «RSU»), 5(4).

Statistical collection. (2012, 2013). Regions of Russia. Socio-economic indexes. Moscow: Rosstat.

Statistical year-book. (1993). The Russian Federation in 1992. Republican information and publishing center.

Roshchin, S.Yu. (2003). The work offer in Russia: microeconomic analysis of economic activity of the population, WP3/2003/02 pre-print. Moscow: HSE.

Roshchin, S.Yu. (2005). Whether women are equal to men?, Population and society, 219 - 220. http://demoscope.ru/weekly/2005/ 0219/tema03.php

Roshchin, S.Yu., Solntsev, S.A. (2006). Who overcomes «a glass ceiling»?: vertical gender segregation in the Russian economy, WP4/2006/03 Pre-print. Moscow: GU HSE.

Roshchina, Ya.M. (2005). Differentiation of the income and education in Russia», Education Questions, 4, $274-297$.

The statistical bulletin of 2011 (2011). Tendencies on a labor market (analytical research), Federal State Statistics Service, http://www.gks.ru/

The statistical reference book. (1932). Labor in the USSR, State social and economic publishing house. Moscow. Leningrad.

Statistical collection. (2003, 2005, 2007, 2009, 2011, 2013). Work and employment in Russia. Moscow: Rosstat.

The education level is higher, the risk of unemployment (2004). Population and society, 167-168, http://demoscope.ru/weekly/2004/ 067/barom03.php

Statistical materials. (1965). Number, structure and movement of the population of the USSR, Moscow: Statistical publishing house.

The Global Gender Gap Report 2013. http://www3.weforum.org/docs/WEF_GenderGap_Report_2013.pdf

Ogloblin, C. (2005). The Gender Earnings Differential in Russia After a Decade of Economic Transition, Applied Econometrics and International Development, 5(3), 5-26. 
ISSN 2039-2117 (online) ISSN 2039-9340 (print)
Mediterranean Journal of Social Sciences MCSER Publishing, Rome-Italy
Vol 6 No 3 S4 May 2015 